Research Article

\title{
Pars Plana Vitrectomy in Rhegmatogenous Retinal Detachment in Paediatric Patients in Dr. Cipto Mangunkusumo Hospital, Indonesia 2017
}

\author{
Faresa Hilda, Ari Djatikusumo, Elvioza Elvioza, Gitalisa A. Adriono, Anggun R. Yudantha, Mario \\ M. Hutapea, Andi A. Victor*
}

Department of Ophthalmology, Faculty of Medicine Universitas Indonesia - Dr. Cipto Mangunkusumo National Hospital, Jakarta

\author{
*Corresponding author: arvimadao@yahoo.com \\ Received 23 November 2020; Accepted 17 August 2021 \\ https://doi.org/10.23886/ejki.9.4.94
}

\begin{abstract}
In the past decades, indications for PPV in paediatric patients has been rising with large heterogeneity outcomes among studies. Our objective is to present a pilot descriptive study in Indonesia, regarding pars plana vitrectomy (PPV) success rate in paediatric patients with rhegmatogenous retinal detachment (RRD) in Dr. Cipto Mangunkusumo Hospital (CMH). A retrospective study was conducted on 16 paediatric eyes diagnosed for RRD and treated in CMH during the period of January 2017 to December 2017. A total of 16 $R R D$ eyes were identified in 15 individuals. Majority of the patients were male and were in the age group of 12-18 years. There were 13 patients undergone PPV with or without SB. Functional anatomical success rate was determined from the macula status while functional success rate on final BCVA. Among 16 patients, 14 had constant or increased final BCVA and 11 had reattached macula. The success rate of PPV in terms of anatomical outcome was 11 out of 16 eyes and in functional outcome was 8 out of 16 eyes.
\end{abstract}

Keywords: pars plana vitrectomy, paediatric ophthalmology, rhegmatogenous retinal detachment.

\section{Karakteristik dan Hasil Vitrektomi Pars Plana pada Pasien Pediatrik di Divisi Vitreoretina Rumah Sakit Cipto Mangunkusumo Tahun 2017}

\begin{abstract}
Abstrak
Indikasi tindakan vitrektomi pars plana (PPV) pada pasien pediatrik bertambah secara signifikan dalam beberapa dekade terakhir. Penelitian ini dilakukan sebagai studi awal di Indonesia, terkait tingkat keberhasilan PPV pada pasien anak dengan rhegmatogenous retinal detachment (RRD) khususnya di RS Cipto Mangunkusumo (RSCM). Studi retrospektif dilakukan terhadap 16 mata RRD pada 15 pasien anak di RSCM pada periode Januari 2017 - Desember 2017. Mayoritas pasien merupakan laki-laki dalam kelompok umur 12-18 tahun. Terdapat 13 pasien yang menjalani PPV dengan atau tanpa scleral buckle (SB). Tingkat keberhasilan anatomi dilihat dari status penempelan makula, sementara tingkat keberhasilan fungsional dinilai dari visus akhir. Tingkat keberhasilan anatomi PPV dalam studi ini adalah 11/16 mata, dan tingkat keberhasilan fungsional mencapai 8/16 mata.

Kata kunci: vitrektomi pars plana, oftalmologi pediatrik, rhegmatogenous retinal detachment.
\end{abstract}




\section{Introduction}

Indications of pars plana vitrectomy (PPV) in paediatric patients has been rising, covering rhegmatogenous retinal detachment (RRD), vitreal haemorrhage $(\mathrm{VH})$, retinopathy of prematurity (ROP), persistent fetal vasculature (PFV), familial exudative vitreoretinopathy (FEVR), and endophthalmitis. ${ }^{1}$ Paediatric PPV success rate are affected by several factors including the relatively smaller anatomical morphology and the existence of any congenital disorder. ${ }^{1}$

The incidence of paediatric retinal detachment ranged $3.32-6.6 \% .^{2-3}$ The prevalence and incidence of paediatric retinal detachment in Indonesia have never been reported due to its complexity compared to adults, i.e. children unawareness of visual impairment, late hospital admission, and difficulty to declare the disease's onset and duration. Delayed treatment might lead to macula detachment (macula off)and proliferative vitreoretinopathy (PVR). Several predisposing factors for retinal detachment are congenital disease, myopia, trauma, and history of intraocular surgery. Children often present with worse functional and anatomical success compared to adults, with a wide range of heterogeneity from $10 \%$ to $80 \%{ }^{3}$ Therefore, treating paediatric retinal detachment cases is a peculiar challenge for vitreoretinal surgeons.

This is a pilot study in Indonesia reporting the outcome of PPV treatment in paediatric RRD patients in Dr. Cipto Mangunkusumo Hospital $(\mathrm{CMH})$, Jakarta, Indonesia.

\section{Methods}

A retrospective study on 16 paediatric eyes diagnosed for RRD and treated in (CMH) in January 2017 to December 2017. Inclusion criteria were all patients aged $\leq 18$ years (in time of surgery) who underwent vitrectomy. Patients' consent was obtained and who were loss to follow up and or with incomplete medical records, were excluded.

Initial best corrected visual acuity (BCVA) was patient's best corrected sight before underwent vitrectomy (pre-surgery). Final BCVA, was patient's best corrected sight after vitrectomy (post-surgery). Anatomical success rate, was patient's retinal condition after vitrectomy, expected to be in attached condition compared to detached condition. Functional success rate was patient's final BCVA improvement compared to initial BCVA. All available medical records fulfilling the inclusion criteria were collected. Data retrieved including demographic status (age, gender, domicile), clinical status (onset, laterality, main diagnosis, initial and final BCVA, initial and final retinal and or macula status, tear location, proliferative vitreoretinopathy, follow-up). Data retrieved were shown and counted using microsoft excel.

Table 1. Demographical and Clinical Characteristics of the Subjects

\begin{tabular}{|c|c|}
\hline Characteristics & Frequency \\
\hline \multicolumn{2}{|l|}{ Gender $(n=15)$} \\
\hline Male & 10 \\
\hline Female & 5 \\
\hline \multicolumn{2}{|l|}{ Age $(n=15)$} \\
\hline $0-<12$ year & 2 \\
\hline $12-\leq 18$ year & 13 \\
\hline \multicolumn{2}{|l|}{ Age $(n=16)$} \\
\hline$<12$ years & 2 \\
\hline $12-\leq 18$ years & 14 \\
\hline \multicolumn{2}{|l|}{ Onset $(n=16)$} \\
\hline$<2$ weeks & 6 \\
\hline$\geq 2$ weeks & 10 \\
\hline \multicolumn{2}{|l|}{$\operatorname{BCVA}(n=16)$} \\
\hline Light Perception (LP) & 3 \\
\hline $1 / 300$ & 7 \\
\hline $1 / 60$ & 3 \\
\hline$>1 / 60$ & 3 \\
\hline \multicolumn{2}{|l|}{ Risk factor $(\mathrm{n}=16)$} \\
\hline High myopia* & 7 \\
\hline Trauma & 6 \\
\hline Others & 3 \\
\hline \multicolumn{2}{|l|}{ Macula status $(n=16)$} \\
\hline Attached (on) & 4 \\
\hline Detached (off) & 12 \\
\hline \multicolumn{2}{|c|}{ Number of retinal break $(n=16)$} \\
\hline Single & 11 \\
\hline Multiple & 3 \\
\hline None/not found & 2 \\
\hline \multicolumn{2}{|c|}{ Location of retinal break $(n=16)$} \\
\hline Superior & 6 \\
\hline Inferior & 2 \\
\hline Temporal & 2 \\
\hline Nasal & 0 \\
\hline$>1$ quadrant & 4 \\
\hline None/not found & 2 \\
\hline \multicolumn{2}{|c|}{ Proliferative vitreoretinopathy $(P V R)(n=16)$} \\
\hline Grade B & 5 \\
\hline Grade C & 11 \\
\hline
\end{tabular}

${ }^{*}$ High myopia $=$ BCVA $\leq-5,00 \mathrm{D}$ 


\section{Results}

A total of 16 RRD eyes were identified in 15 individuals during the period of January 2017 to December 2017 in CMH. Demographical and clinical characteristics of the patients were summarized in Table 1. Majority of the subjects were male $(10 / 16)$ with the most prevalent age 12 to 18 years old. There were 10 subjects with onset of $\geq 2$ weeks before hospital admission. The majority pre-surgery BCVA were $<1 / 300(10 / 16)$, with the most prevalent risk factor of high myopia (7/16). There were 11 subjects had single retinal break, with the most prevalent location was in superior quadrant including supero-temporal quadrant (6 patients). There were 11 subjects had grade C PVR while 5 patients had grade B PVR.

Most subjects undergone therapy $\geq 2$ weeks after onset as seen on Table 2. All subjects undergone vitrectomy had been given silicone oil as an internal tamponade. There were 2 subjects undergone re-surgery (partial silicone oil evacuation) due to glaucoma complication.

Table 2. Type of Surgery and Duration from Onset to Surgery

\begin{tabular}{lc}
\hline Type of Surgery & Frequency \\
\hline Main Surgery $(n=16)$ & \\
Vx + EL + SO \pm SB + cryopexy & 14 \\
SB + Tyre + gas SF6 25\% + cryopexy & 2 \\
Duration from onset to surgery $(n=16)$ & \\
$\quad<2$ weeks & 7 \\
$\geq 2$ weeks & 9 \\
Re-surgery $(n=5)$ & \\
Re-vitrectomy + EL + SO & 3 \\
Partial SO evacuation & 2 \\
\hline
\end{tabular}

$\mathrm{Vx}=$ vitrectomy, $\mathrm{EL}=$ endo-laser, $\mathrm{SO}=$ silicone oil, $\mathrm{SB}=$ scleral buckle

Duration from onset to surgery is the duration from diagnosis to the first surgical treatment. Anatomical success rate was determined from post-surgery reattached macula, found in 11 out of 16 patients, while 5 patients were detached macula. Functional success rate was determined from BCVA while anatomical success rate was determined from macula status, whether it was attached or detached. Out of 14 from 16 patients undergone vitrectomy with or without scleral buckle, while only 2 patients undergone scleral buckle only. Half subjects $(8 / 16)$ undergone vitrectomy without scleral buckle, while 6 patients undergone vitrectomy with scleral buckle. From all these approaches, only 3 patients had descended final BCVA while 8 of 16 patients had final BCVA $>1 / 300$ thus considered functionally successful, while the rest $50 \%$ had BCVA $<1 / 300$ (Table 3 ).

Table 3. The Comparison of BCVA between Vitrectomy and Scleral Buckle

\begin{tabular}{lcc}
\hline $\begin{array}{c}\text { Pre- and Post- } \\
\text { surgery BCVA }\end{array}$ & $\begin{array}{c}\text { Vitrectomy with } \\
\text { or without Scleral } \\
\text { Buckle } \\
(\mathbf{n = 1 4 )}\end{array}$ & $\begin{array}{c}\text { Scleral } \\
\text { Buckle } \\
(\mathbf{n}=\mathbf{2})\end{array}$ \\
\hline Rise & 7 & 1 \\
Descent & 3 & 1 \\
Constant & 4 & 0 \\
\hline
\end{tabular}

\section{Discussion}

Indications for PPV in paediatric patients has been rising in the past decades. In this study, PPV indication met the 16 RRD cases. Moisseiev et al ${ }^{4}$ reported 65 paediatric patients undergone PPV with the most prevalent etiology due to penetrating trauma (33.84\%) and RRD (24.61\%). In the area of RRD, around $62.5 \%$ were due to high myopia while $37.5 \%$ were due to ocular trauma. A study involving 60 paediatric eyes by Karel ${ }^{5}$ found that PPV performed in paediatrics due to RRD (48\%). Those findings were similar with our results, with the PPV done in paediatrics due to RRD (55\%).

Majority of the subjects were male $(66.7 \%)$ with the predominant age group of $12-18$ years old $(86.7 \%)$. Karel ${ }^{5}$ found similar results with male as the majority subjects $(75 \%)$ yet with the most predominant age group was $6-15$ years old.

During the period of January 1, 2017 to December 31, 2017, a total of 526 patients with retinal detachment had undergone either PPV or scleral buckling at $\mathrm{CMH}$. Among them, only 16 out of 526 were paediatrics $(3.04 \%)$. This finding was similar with Meier et $\mathrm{al}^{2}$ who reported the incidence of retinal detachment in paediatrics ranged $3.2-6.6 \%$.

Several factors identified to increase risks for RRD were myopia (43.75\%) and trauma (37.5). Gurler et $\mathrm{al}^{6}$ also reported those two factors as the most prevalent risk factors for developing RRD myopia (40\%) and trauma (36.6\%). Post-traumatic RRD in paediatrics might occur and progress slowly, therefore often unrealized. Trauma causes sudden disturbance and shifting of vitreous humour, leading to retinal breaks even at the strongest vitreo-retinal adhesion, i.e. vitreous base, fovea, 
lattice degeneration, and chorioretinal cicatrix. ${ }^{7} \mathrm{Up}$ to $30 \%$ RRD in paediatrics were bilateral. ${ }^{8}$

RRD in paediatrics were often underdiagnosed, as the children were unaware of their symptoms, thus leading to delayed onset to hospital admission and increased risk for detached retina (macula off). Majority subjects in this study $(75 \%)$ were presented with macula off. This finding were in concordance to other reports, with detached macula found in $26-98 \% .^{6}$ Single retinal tear was the most common break $(68.75 \%)$ with superior quadrant as the most prevalent retinal tear location (37.5\%). McElnea et $\mathrm{al}^{9}$ reported $7.1 \%$ subjects in their study presented with multiple retinal tear.

The goal of RRD treatment are to release vitreous traction to retina and to reattach the neurosensory retina into retinal pigment epithelium (RPE). PPV is the chosen therapy in complex ablatio retina, i.e. multiple tears, grade C PVR, tear in the posterior area, vitreous cloudiness, and the presence of epiretinal membrane. However, PPV in children is challenging due to strong vitreoretinal adhesion. ${ }^{9}$ Scleral buckle is indicated in diseases such as RRD without PVD, retinal dialysis, atrophic holes, tear located in the anterior retina, inferior retina, and grade A or B $360^{\circ} \mathrm{PCR}$ which needed vitreous base support. ${ }^{10}$

In this study, 14 out of 16 subjects undergone PPV as an initial procedure, while only 2 eyes undergone pure scleral buckle procedure. As an internal tamponade, silicone oil was the chosen agent used in PPV while SF6 $25 \%$ gas was used following a scleral buckle procedure. An advantage offered by SO in paediatrics is no need for positioning, while in gas tamponade patients need to maintain face-down positioning for weeks which is troublesome in children. The use of SO also shown rapid visual rehabilitation with less risk for amblyopia. ${ }^{4}$ While the indications for primary vitrectomy in paediatric eyes include poor fundal view, giant or posterior retinal break, and severe PVR. Within the last 20 years, SB has been used as an initial procedure in cases without severe PVR. ${ }^{11}$ These findings were in concordance with Rejdak et $\mathrm{al}^{10}$ who used silicone oil following $93 \%$ patients undergone PPV.

Al Zaaidi et al $^{12}$ reported $85 \%$ of their subjects undergone PPV as the primary procedure, with $16.26 \%$ undergone PPV without scleral buckling. The subjects undergone a combination therapy of $\mathrm{PPV}+\mathrm{SB}$ was relatively higher in Al Zaaidi et $\mathrm{al}^{12}$ compared to this study ( $68 \%$ vs $37.5 \%$ ).

Errera et $\mathrm{al}^{11}$ reported primary SB procedure in paediatric RRD with anatomical success rate of $73 \%$ (76/104 eyes). Procedure failure was related to multiple retinal tears, multiple $(>3)$ quadrant tears, horseshoe-shaped retinal tear, and unidentified retinal tear. ${ }^{11}$ In this study, there were 2 subjects undergone pure SB procedure as the primary treatment, with one subject achieved retinal reattachment. Several factors thought to support the positive outcome were sooner onset (2 months) with minimal inflammatory process compared to another subject.

Phakic RRD patients undergone the combination treatment of vitrectomy and scleral buckle, had lower risk of retinal re-detachment compared to patients undergone vitrectomy only. Factor affecting its success rate was influenced by wider peripheral visualization in vitrectomy which can reduce PVR occurrence. However, in this study the results were similar between both procedures. Anatomical success rate, evaluated from retinal reattachment in this study was $68.75 \%$. It is relatively lower than the success rate in adults which ranged between $70-80 \%{ }^{8,10}$

Eleven out of 16 subjects were presented with grade C PVR while another 5 eyes were grade $B$ PVR. Al-Zaaidi et al $^{12}$ found $33 \%$ grade C PVR in their study. Feng et al $^{14}$ reported 47 eyes $(52.8 \%)$ had PVR with only 16 eyes (38.1\%) had successful outcome.

In this study $5 / 16$ subjects presented with redetachment after surgery, this was considered to be related to one of these factors: delayed RRD onset (>6 months), severe PVR, or congenital comorbid. Two out of four patients with grade $C$ PVR had re-detachment, occurred 1 month postsurgery (vitrectomy + endo-laser + silicone oil injection). One of them had a comorbid of coat's disease. Factors contributing to re-detachment are residing vitreous body around the location of retinal break and greater inflammatory reaction in children compared to adults. ${ }^{9}$ On the other hand, this study found that 2 subjects with grade $C$ PVR had maintained a status of attached retina following 1 month post-surgery. Both subjects had the combination therapy of vitrectomy, endo-laser, silicone oil, and scleral buckle.

Functional success rate in this study was $50 \%$ $(B C V A>1 / 300)$. Wenick et $\mathrm{al}^{8}$ reported that 30 $40 \%$ subjects in their study achieved $3 / 60-6 / 60$. In this study, one of the factors leading to nonfunctional final BCVA was permanent damage of photoreceptors which is common in chronic retinal detachment. According to the duration from onset 
to hospital admission, 6 subjects came $<2$ weeks, while another 6 subjects came 1-3 months following an onset. However, data regarding disease onset in these subjects were relatively subjective, considering the low rate of children's awareness towards visual impairment. Othercomordibities such as macula cicatrix, coat's disease, post-traumatic macular haemorrhage, all were considered to poor prognosis. Nuzzi et al ${ }^{15}$ estimated poor prognostic factors regarding post-surgical RRD patients were status macula off, grade C PVR or worse, silicone oil injection, poor final BCVA following surgical procedure, and any history of intraocular surgery or trauma. On the contrary, Feng et $\mathrm{al}^{15}$ did not count poor post-surgery BCVA as an indicator for poor final outcome.

Our study used a descriptive approach with limited number of subjects. However we feel the necessity to put these unusual and relatively rare cases into the spotlight as a reference for other ophthalmologists who face similar circumstances. Further longitudinal analytical studies are needed to elaborate more upon this topic.

\section{Conclusion}

The success rate of PPV in terms of anatomical outcome was 11 out of 16 patients and in functional outcome was 8 out of 16 patients.

\section{Conflict of Interest}

The authors declare that there is no conflict of interest regarding the publication of this article. The authors received no specific funding for this work.

\section{References}

1. Mahajan. Limbus-based Vitrectomy Offers Safe Alternative in Pediatric Cases. Retina Today. 2012;67-8. Available from: https://bit.ly/2WtzG8B

2. Meier. Retinal detachment in children: differential diagnosis and current therapy. Klinische Monatsblätter für Augenheilkunde. 2008;225:77990. doi: 10.1055/s-2008-1027515

3. Nuzzi R, Lavia C, Spinetta R. Paediatric Retinal Detachment: A Review. Int J Ophthalmol 2017;10:1592-1603. doi: 10.18240/ijo.2017.10.18.
4. Moisseiev J, Vidne O, Treister G. Vitrectomy and silicone oil injection in pediatric patients. Retina. 1998;18:221-7. doi 10.1097/00006982-19980300000005

5. Karel M. Pars plana vitrectomy in the pediatric population: indications and long- term results. Eur J Opthalmol. 1999;9:231-7. doi 10.1177/112067219900900311

6. Gurler B, Coskun E. Clinical Characteristics and surgical outcomes of pediatric rhegmatogenous retinal detachment. Int Ophthalmol. 2016;3d:521-5. Doi 10.1007/s10792-015-0158-3

7. ElliotD, Papakostas TD. Traumatic Chorioretinopathies. In: Schachat AP, ed. Ryan's Retina. $6^{\text {th }}$ ed. USA: Elsevier; 2018;1757-70.

8. Wenick AS, Baranano DE. Evaluation and management of pediatric rhegmatogenous retinal detachment. Saudi J Ophthalmol. 2012;26:255-63. doi 10.1016/j.sjopt.2012.04.005

9. McElnea E, Stephenson K, Gilmore S, O'Keefe M, Keegan D. Paediatric retinal detachment : aetiology, characteristics and outcomes. Int J Ophthalmol. 2018;11:262-6. doi 10.18240/ijo.2018.02.14

10. Rejdak R, Nowakowska D, Wrona K, Maciejewski $\mathrm{R}$, Junemann AM, Nowomiejska K.Outcomes of Vitrectomy in Pediatric Retinal Detachment with Proliferative Vitreoretinopathy. Journal of Ophthalmology. 2017;2017:8109390. doi $10.1155 / 2017 / 8109390$

11. Errera. Primary scleral buckling for pediatric rhegmatogenous retinal detachment. Retina. 2015;35:1441-9. doi10.1097/IAE.0000000000000480

12. AL-Zaaidi S, AL-Rashaed S, AL-Harthi E, ALKahtani E, El-Asrar AMA. Rhegmatogenous retinal detachment in children 16 years of age or younger. Clin Ophthalmol. 2013;7:1001-14. 1001-1014. doi 10.2147/OPTH.S40056

13. Sabrosa NA, Wong C. Scleral Buckling for RRD: Yes, No or Maybe? Review of Ophthalmology. 2014. Available from: https://www.reviewofophthalmology. com/article/scleral-buckling-for-rrd-yes-no-or-maybe

14. Feng X, Feng K, Hu Y, Ma Z. Clinical features and outcomes of vitrectomy in pediatric ocular injurieseye injury vitrectomy study. Indian J Ophthalmol. 2014;62:450-3. doi: 10.4103/0301-4738.120222

15. Nuzzi R, Lavia C, Spinetta R. Paediatric retinal detachment : a review. Int J Ophthalmol. 2017;10:1592-1603. doi 10.18240/ijo.2017.10.18 